\title{
REALISASI ISI KEPUTUSAN PESAMUAN AGUNG III MUDP BALI NO. 01/KEP/PSM-3 MDP BALI/X/2010 TERKAIT DENGAN ANAK PEREMPUAN TERMASUK BERHAK MEWARIS (STUDI KASUS DI KABUPATEN BULELENG)
}

\author{
Ketut Sudiatmaka \\ UNDIKSHA, Singaraja \\ e-mail: mettasari_88@yahoo.com
}

\begin{abstract}
Abstrak
Latar belakang penelitian ini adalah kajian terhadap status hukum perempuan Bali lemah dari segi pewarisan, karena menurut Hukum Adat Bali yang berhak mewaris hanyalah keturunan pria dan pihak keluarga pria dan anak angkat lelaki.. Wanita di dalam Hukum Adat Masyarakat Bali masih mengalami diskriminasi dari segi ketentuan hukum. Secara umum penelitian ini bertujuan untuk (1) untuk mengetahui bentuk pengambilan kebijakan dalam proses pengambilan keputusan adat perihal waris di kabupaten Buleleng; (2) untuk mengetahui realisasi isi keputusan MUDP Provinsi Bali No.01/Kep/PsM-3/MDP BALI/X/2010, 15 Oktober 2010 tentang perempuan Bali menerima 1/2 dari hak waris purusa setelah dipotong 30\% untuk harta pusaka dan kepentingan pelestarian. (3) Untuk mengetahui pandangan dan keberterimaan perempuan di Kabupaten Buleleng terhadap implementasipsamuan agung III MUDP Bali; (4) untuk mengetahui pengaruh dari penetapan SK MUDP Provinsi Bali No.01/Kep/PsM-3/MDP $\mathrm{BALI} / \mathrm{X} / 2010$, dan daya ikat bagi masyarakat adat di kabupaten Buleleng. Penelitian ini akan dilakukan selama 2 tahun, yaitu dari tahun 2015 sampai dengan tahun 2016. Luaran penelitian dijabarkan sebagai berikut: (1) luaran tahun I: perancangan dan pengembangan kebijakan tentang ketentuan adat yang lebih menjamin hak-hak perempuan secara hukum, dan Buku Ajar. (2) luaran tahun II: artikel ilmiah di jurnal nasional terakreditasi/internasional seperti jurnal Hukum Pandecta, dan rekomendasi yang berkaitan dengan rujukan draft naskah akademik yang dirancang oleh peneliti untuk diusulkan ke instansi terkait sebagai rujukan dalam penetapan hukum. Hasil penelitian Bentuk pengambilan keputusan di wilayah adat sudah menyesuaikan dengan uger-uger adat yang berlaku di masingmasing daerah di Kabupaten Buleleng tempat penelitian dilaksanakan. Untuk dapat dilaksanakan isi Pesamuan Agung III itu, dirasakan sangat perlu adanya perarem-perarem di masing-masing desa adat guna adanya pengenjuh awig yaitu penambahan atau perubahan awig-awig yang telah dimiliki dan berlaku. Dalam aplikasi putusan Pesamuan Agung III MUDP Bali, mendapat respon negarif dari anak laki-laki yang kurang memahami asas komunalitas di antara anak laki-laki maupun perempuan, tetapi jika dilihat pemberi waris dalam bentuk paweweh tampaknya anak laki-laki pun tidak keberatan. Tanggapan positif masyarakat Buleleng menghormati hak perempuan Bali dalam bidang kehidupan sosial dan ekonomi dengan kebijaksanaan memberikan kesempatan sebagai pewaris di dalam keluarga.
\end{abstract}


Kata Kunci: Decision Tree, Diskriminasi Perlakuan, Hukum Adat, Kebijakan, Keputusan, Kontradiktif , Mewaris, Perempuan Bali.

\begin{abstract}
The background of this research is the study of the legal status of women Bali weak in terms of inheritance, because according to the Customary Law Bali rightful heir only male offspring and the families of men and male foster child. Women in the Indigenous people of Bali are still suffering discrimination in terms of provision law. In general, this study aims to (1) to determine the form of policy making in the traditional decision-making process regarding inheritance in Buleleng district; (2) to determine the actual contents of Bali Province MUDP decision No.01/Kep/PSM-3/ MDP BALI/X/2010, October 15, 2010 on Bali receives $1 / 2$ of the women's inheritance rights purusa after the deduction of $30 \%$ for inheritance and conservation purposes. (3) To know the views and acceptance of women in Buleleng against the great implementasion pesamuan III MUDP Bali; (4) to determine the effect of fixing SK MUDP Bali Province No.01/ Kep/PSM-3/MDP $\mathrm{BALI} / \mathrm{X} / 2010$, and the holding capacity for indigenous peoples in Buleleng regency. This study will be conducted over two years, ie from 2015 to 2016. The output of the study described as follows: (1) the outcome of the first: the design and development of a policy on customary provisions that guarantee the rights of women in law, and Textbook , (2) the outcome of II: scientific articles in journals accredited national / international as Pandects law journal, and recommendations with regard to the referral draft academic paper designed by the researchers to be proposed to the relevant institutions as a reference in determining the law. The form of the decision-making research results in the area of indigenous adjust with uger-uger custom prevailing in each region in Buleleng where research is conducted. To be able to browse the congregation carried Agung III, perceived necessary for perarem-perarem in each indigenous village to the pengenjuh awig that additions or changes awig awig which has been owned and is valid. In applications congregation Court ruling III MUDP Bali, getting a response negarif of boys who do not understand the principle of commonality among boys and girls, but when seen in the form of inheritance giver paweweh boy apparently did not mind. Positive response community Bali Buleleng respect women's rights in the areas of social and economic life with the wisdom of giving a chance as heir in the family.
\end{abstract}

Keywords: Decision Tree, Discrimination treatment, Customary Law, Policy, Decisions, Contradictory, heir, Women Bali.

\section{PENDAHULUAN}

Negara Indonesia adalah negara hukum berdasarkan ketentuan Pasal 1 ayat (3) Undang-Undang Dasar Negara Republik Indonesia Tahun 1945. Dalam kerangka pembangunan hukum nasional Indonesia beberapa sumber hukum memberikan pengaruh terhadap perkembangan tatanan hukum nasional, seperti hukum peninggalan kolonial Belanda yang masih relevan karena disesuaikan dengan jiwa Pancasila dan konstitusi negara di justifikasi menurut Pasal II Aturan Peralihan dan Asas Konkordansi, meliputi KUH Perdata, KUH Pidana, KUH Dagang; Hukum 
Agama, Kebiasaan, Hukum Adat, Jursiprudensi, memberikan ragam corak terhadap khasanah kajian pengembangan hukum nasional secara bertahap. Hukum Adat merupakan salah satu hukum asli Indonesia yang tumbuh dan berkembang seiring dengan dinamika perkembangan masyarakat.

Hukum Adat pada dasarnya berkedudukan memperkaya khasanah hukum nasional Indonesia. Hukum Adat menjadi tumpuan masyarakat adat bertalian dengan keputusan-keputusan adat yang dijumpai penetapannya dalam kontak sosial manusia di lingkungan masyarakat adat di seluruh wilayah nusantara. Fungsi keputusan adat yang dimaksudkan di sini adalah memberikan pembatasan oleh ketentuan-ketentuan yang mengatur tingkah laku dan sikap mereka, karena jika tidak demikian akan terjadi ketidak seimbangan dalam masyarakat. Hukum Adat bagi warga masyarakat adat mempunyai beberapa indikator penting dalam menunjukkan peranannya sebagai a tool of a social engineering (rekayasa sosial yang bertujuan untuk mengarahkan menuju keteraturan dan ketertiban yang orientasinya ingin menyasar aspek keadilan bagi masyarakat). Pertama, Hukum Adat yang realisasinya dapat berupa keputusan adat dari hasil pesamuhan majelis adat secara substantif memuat ketentuan yang mengatur tingkah laku manusia atau yang menjadi pedoman manusia untuk berperilaku guna menjaga keseimbangan kepentingan mereka dalam masyarakat. Kedua, memberikan peluang besar untuk perwujudan aspek keadilan bagi masyarakat dalam kerangka menerapkan prinsip persamaan di muka hukum dan pemerintahan dan wajib menjunjung hukum dan pemerintahan tanpa terkecuali bagi masyarakat Indonesia secara keseluruhan (equality before the law), baik kaum laki-laki maupun perempuan. Ketiga, Hukum Adat dalam wujud Keputusan Majelis Adat dinilai memberikan kontribusi yang besar dalam penetapan kebijakan yang memenuhi unsur pelayanan publik bagi anggota masyarakat sampai ke tingkat lapisan masyarakat paling bawah (Daliyo, 2012 : 15).

Ketentuan pasal 18 UUD Negara Republik Indonesia 1945 menyebutkan bahwa negara Indonesia menghormati keberadaan kesatuan masyarakat hukum adat beserta segenap aspek sosial budaya yang melingkupi di setiap pengambilan keputusannya. Jadi, berdasarkan isi ketentuan konstitusi tersebut di atas, tampak jelas bahwa ketentuan hukum adat mengikat masyarakat adat dan akan menimbulkan akibat hukum tertentu apabila dilanggar. Namun, dalam substansi ketentuan adat tidak jarang menimbulkan reaksi kontradiksi bagi warga masyarakat adat untuk mengkaji kembali setiap kebijakan yang ditetapkan atas nama adat. Bahkan tidak jarang masyarakat menilai bahwa antara ketentuan yang ditetapkan dengan pelaksanaannya di lapangan sering kali dalam penerapannya mengalami tumpang tindih. Salah satu permasalahan yang muncul misalnya perihal pengaturan hak anak perempuan yang berhak mewaris menimbulkan perdebatan panjang di kalangan pemangku kebijakan dengan masyarakat yang disasar kebijakan tersebut.

Hukum adat waris adalah hukum yang memuat peraturan-peraturan yang 
mengatur proses meneruskan serta mengalihkan barang-barang harta benda dan barang-barang tidak berwujud dari satu generasi manusia kepada keturunannya. Sistem kekeluargaan yang dikenal pada masyarakat Bali adalah sistem Patrilineal, yang melalui garis keturunan laki-laki (Purusa) dan merupakan generasi penerus orang tuanya, sedangkan anak perempuan bukuan generasi penerus orang tuanya. Hal tersebut dengan jelas dan tegas dirumuskan dalam salah satu pasal (pawos) dalam awig-awig desa pakraman. Kedudukan anak perempuan Bali dalam hal mewaris hanya mempunyai hak menikmati harta guna kaya orang tuanya selama ia belum kawin, apabila ia kawin, maka hak menikmati menjadi gugur. Pada tanggal 15 Oktober 2010 Majelis Utama Desa pakraman (MUDP) Bali mengadakan Pasamuan Agung III, yang intinya melakukan terobosan terhadap hukum adat waris bali. Pada Pasamuan Agung III MUDP Bali tersebut telah diputuskan bahwa anak perempuan berkedudukan sebagai ahli waris terbatas.

Kontradiksi antara law in book dan law in action dapat terjadi tidak terlepas dari sistem sosial budaya yang melingkupi sistem pewarisan masyarakat Bali. Masyarakat Bali memiliki sistem pewarisan yang berakar pada sistem kekerabatan patrilinial yang menyebabkan sistem pertalian kewangsaan lebih dititikberatkan menurut garis keturunan pria. Maka kedudukan pria lebih diutamakan dari wanita. Pria adalah penerus keturunan bapaknya yang ditarik dari satu bapak asal, sedangkan wanita disiapkan untuk menjadi anak orang lain yang akan memperkuat keturunan orang lain. Oleh karena itu apabila satu keluarga tidak mempunyai anak laki-laki dan tidak mempunyai keturunan dikatakan "putus keturunan". Sistem kekerabatan ini di Bali dikenal sebagai sistem keturunan laki-laki purusha (Hadikusuma, 1987 : 33).

Kondisi sosial budaya matri lokal yang masih dinilai mengalami diskriminasi dapat dilihat dari gambaran perihal waris yang ditentukan dengan mendasarkan pada garis keturunan lakilaki. Bagi keluarga yang hanya memiliki anak perempuan dan sama sekali tidak diberikan keturunan anak laki-laki, maka dianggap ini sebuah malapetaka, nasib tidak mujur dan berbagai makna yang mengkhawatirkan, Anak perempuan, tidak sebagai penerus keturunan dalam Hukum Hindu pada Masyarakat Adat di Bali yang menganut sistem patrilinial. Apabila terjadi perkawinan di luar lingkungan keluarga purusha (sistem keturunan laki-laki), maka ia tidak mendapatkan hak terhadap harta kekayaan orang tuanya. Anak laki-laki yang mewarisi semua harta warisan, keturunan, membayar hutang orang tua, dan melakukan upacara kematian ngaben jika orang tua_meninggal, sebab anak laki-laki sebagai garis purusha (sistem keturunan laki-laki) yang dipersiapkan untuk melanjutkan keturunan. Tidak demikian dengan nasib dan kedudukan anak perempuan, apabila anak perempuan menikah dengan orang yang bukan dalam garis purusha (sistem keturunan laki-laki) maka ia dianggap sudah keluar dari lingkungannya (clan, soroh atau marga), maka anak perempuan tidak memiliki kewajiban terhadap orang tua dan clannya. Hal tersebut menyebabkan 
wanita tidak diberikan hak untuk mewaris. Hanya jika saudara prianya mengikhlaskan untuk memberikan suatu pemberian sama rata atau memilih untuk tidak menikah sepanjang hidup atau wanita dapat berposisi purusha (sistem keturunan laki-laki) apabila perkawinan dilakukan dengan sistem nyentana (Wibawa, 2006 : 98-99).

Sistem perkawinan nyentana adalah sistem perkawinan dimana pihak perempuan tidak keluar dari clan atau kerabat ayah kandungnya namun membawa pihak laki-laki masuk ke dalam kerabat ayah kandung wanita sehingga pria berubah kedudukannya menjadi wanita dan wanita berubah kedudukannya menjadi pria. Sering terjadi saat seorang anak perempuan menikah dan keluar dari lingkungan clan atau kerabat dari orang tuanya, orang tua memberikan harta sebagai bawaan dalam pernikahan yang disebut harta tetatadan (harta awaan) seperti harta bergerak contohnya perhiasan, motor dan mobil.

Hal ini memberikan gambaran relasi timpang dalam aspek gender antara perempuan dan laki-laki pada sistem pewarisan adat di Bali sangat jelas terungkap bahwa kedudukan perempuan Bali sangat subordinatif terhadap laki-laki Bali, dan gerakan dari laki-laki untuk mengukuhkan proses itu sangat kuat. Hal tersebut menimbulkan keluhan-keluhan dari kaum perempuan di Bali terhadap ketidakadilan keadaan tersebut, sementara itu dalam berbagai instrumen Peraturan Perundangan Nasional telah terumus berbagai instrumen hukum yang menjamin persamaan hak antara wanita dan pria. Melihat pengaturan yang normatif seolah-olah terdapat jurang antara apa yang terumus dalam Hukum Adat di satu sisi dan Hukum Nasional di sisi yang lain, Subekti (1991 : 4). Pada kenyataan sehari-hari selalu saja dapat dijumpai perempuan-perempuan yang mengalami diskriminasi dalam hal waris, dan tidak mempunyai akses kepada Peradilan Negara, Irianto (2005 : 4). Keadaan,.

Perkembangan terakhir mulai 2010 sampai dengan sekarang, Masyarakat Adat Bali telah mengalami perkembangan khususnya terhadap persamaan hak dalam pewarisan bagi perempuan Bali yang telah diatur dalam Keputusan Majelis Utama Desa Pakraman Bali (MUDP) Bali No. 01/KeP/Psm-3/MDP Bali/X/2010, tanggal 15 oktober 2010, tentang hasilhasil Pasamuan Agung III MUDP Bali memutuskan mengenai kedudukan suami istri dan anak terhadap harta pusaka dan harta gunakaya, termasuk hak waris anak perempuan (anak kandung maupun anak angkat).

Salah satu implementasi keputusan MUDP ini terlihat di Kota Denpasar, di mana di Denpasar Keputusan Majelis Utama Desa Pakraman Bali (MUDP) Bali No. 01/ KeP/ Psm-3/ MDPBali/ X/ 2010 ini belum sepenuhnya dilaksanakan oleh Masyarakat Adat Bali di Desa Pakraman mereka. Hasil keputusan MDP (Majelis Desa Pakraman) Bali ini merupakan pilihan hukum di dalam proses pembagian waris bagi anak perempuan.

Berdasarkan latar belakang dan kajian empiris di atas, maka permasalahan pokok dari penelitian ini adalah : bagaimanakah penerimaan masyarakat terkait dengan SK MUDP Provinsi Bali No.01/Kep/PsM-3/MDP $\mathrm{BALI} / \mathrm{X} / 2010$ di Kabupaten Buleleng. 
Permasalahan pokok ini dapat dirinci menjadi beberapa permasalahan penelitian, yaitu : (1) Bagaimanakah Bentuk Pengambilan Kebijakan dalam Proses Pengambilan Keputusan Adat Perihal Perkawinan? (2) Bagaimanakah Realisasi Isi Keputusan MUDP Bali No.01/Kep/PsM-3/MDP BALI/X/2010 tentang Perempuan Bali yang Menerima 1/3 Harta Warisan Purusa Setelah Dipotong 1/3 untuk Harta Pusaka dan Kepentingan Pelestarian?;

Bagaimanakah Realisasi Isi Keputusan MUDP Bali_No.01/Kep/PsM-3/MDP BALI/X/2010 tentang Perempuan Bali yang Menerima 1/3 Warisan Purusa Setelah Dipotong 30\% untuk Harta Pusaka dan Kepentingan Pelestarian?; (4) Bagaimanakah Pengaruh dari Penetapan Isi SK MUDP Bali No.01/Kep/PsM-3/MDP BALI/X/2010 dan Daya lkat Putusan MUDP?

\section{METODE}

Pendekatan yang digunakan dalam penelitian ini adalah (1) Pendekatan yuridis empiris dengan melakukan pengkajian terhadap realisasi Keputusan Pesamuan Agung III MUDP Bali No. 01/Kep/PSM-3MDP Bali/X/ 2010, 15 Oktober 2010. Pendekatan yuridis empiris diterapkan dalam lingkup penelitian yang berkaitan dengan kegiatan analisis yang dilakukan menggunakan metoda-metoda analisis yang bersifat teoritis atau normatif. Pendekatan ini digunakan untuk menghasilkan usulan atau konstruksi formulasi kebijakan yang dapat memecahkan masalah. (2) Pendekatan empiris: diterapkan dalam rangka menjustifikasi hasil kegiatan analisis dan evaluasi yang dilakukan berdasarkan pendekatan teoritis dan evaluatif.
Pendekatan ini dapat digunakan untuk menjelaskan sebab akibat dari suatu kebijakan. Dalam pendekatan ini digunakan metoda-metoda yang dapat menjelaskan hubungan sebab akibat berdasarkan analisis kondisi faktual yang diperoleh dari observasi terhadap gejala-gejala yang timbul.

Penelitian ini akan dilakukan di Kabupaten Buleleng. Pemilihan lokasi ini didasari oleh beberapa rasional, yaitu: (1) untuk mengungkap efektifitas keberlakuan hukum dalam lingkup masyarakat adat terutama menyangkut perihal status perempuan berhak mewaris dilihat dari segi daya ikat keputusan MUDP dalam hal pembagian warisan bagi perempuan yang dijalankan masyarakat Bali di Kecamatan sampel kecamatan di Kabupaten Buleleng setelah berlakunya Keputusan Pasamuan Agung Majelis Utama Desa Pakraman Bali (MUDP) Bali No. 01/KeP/PsM-3/MDP Bali/X/ 2010. (2) hampir di sebagian wilayah Buleleng pernah terjadi konflik adat yang disulut oleh permasalahan perempuan berhak mewaris, (3) sampai saat ini hampir di Kabupaten Buleleng belum melegitimasi secara yuridis formalefektifitas realisasi isi keputusan MUDP tersebut, sehingga sering menjadi pemicu terjadinya konflik pewarisan dan konflik penerusan keturunan serta konflik adat. Berdasarkan rasional di atas, maka penelitian ini dilihat dari lokasi pelaksanaannya memilih Kabupaten Buleleng sebagai lokasi penelitian.

Obyek penelitian adalah Realisasi Isi Keputusan MUDP ada di Kabupaten Buleleng. Data primer terangkum dalam studi pendahuluan, data tersebut dikumpulkan melalui kunjungan 
langsung ke objek penelitian guna mendapatkan data yang diperlukan, yaitu dengan cara wawancara terstuktur dan dan sistematis dengan distribusi angket selaku sebaran informasi serta diperkuat dengan acuan observasi ke lapangan. Data diambil bukti otentik dokumen keputusan MUDP yang dijadikan pedoman pengkajian realisasinya oleh penelitian. variabel dalam penelitian ini terdiri dari variabel bebas adalah Keputusan Pasamuan Agung Majelis Utama Desa Pakraman Bali (MUDP) Bali No. 01/KeP/PsM3/MDP Bali/X/2010. Sedangkan, variabel terikatnya adalah kedudukan perempuan Bali dalam memperjuangkan hak mewaris. Data primer diperoleh dari Analisis perilaku pelaku pelaksana keputusan MUDP termasuk masyarakat yang disasar keberlakuan keputusan MUDP tersebut. Data sekunder : dari data yang diambil dari Majelis Desa Pakraman di lokasi penelitian, referensi yang relevan dengan topik penelitian, dari studi literatur atau studi kepustakaan (desk research), data pemangku kebijakan prajuru adat desa pakraman maupun warga adat, Identifikasi produk-produk di lokasi penelitian, laporan hasil studi atau kajian terdahulu, publikasi yang relevan dan terkait.

Analisis data dalam penelitian ini menggunakan analisis deskriptif. Analisis data kualitatif hasil penelusuran data: (1) Data jenisbahan hukum berupa Keputusan MUDP, Data monografi desa, (2) Studi empiris yang mencakup studi, terhadap kebijakan publik, (3) sumberdaya aparatur adat dalam hal perancangan, pengusulan, proses, pembahasan, dan penetapan keputusan publik, (4) Evaluasi terhadap Aplikasi.
Dalam pelaksanaannya, peneliti mengunakan beberapa alat bantu pengumpulan data, yaitu: wawancara, (2) observasi partisipatif, (3) pencatatan dokumen, (4) kuisioner. Data yang terkumpul dalam penelitian ini berupa data data kuantitatif. Keseluruhan data ini dianalisis dengan menggunakan teknik analisis deskriptif dan statistik sesuai dengan karakteristik data yang dibutuhkan untuk mengurai masing-masing penelitian.

permasalahan

\section{HASIL DAN PEMBAHASAN \\ Bentuk Pengambilan Kebijakan dalam Proses Pengambilan Keputusan Adat Perihal Perkawinan}

Pelaksanaan pewarisan sampai saat ini berlaku hukum adat sebagaimana diatur dalam Residen BaliLombok sejak tahun 1915 yaitu pewarisan adat patriarkhi atau sering disebut dengan pewarisan Lempeng ke Purusa (mengikuti garis laki-laki). Dalam hal penyelesaian kasus-kasus pewarisan pada keluarga krama desa adat, prajuru desa adat pernah diminta ikut menyelesaikan baik di tingkat keluarga maupun dadia, sifat penyelesaiannya adalah dengan pendekatan konsiliasi/mediasi dalam mengupayakan penyelesaian damai.

Keikutsertaan prajuru desa adat menyelesaikan kasus-kasus pewarisan, ketika di tingkat keluarga maupun dadia tidak bisa diselesaikan. Prajuru desa adat pada dasarnya sangat mengutamakan penyelesaian kasus pewarisan melalui pendekatan kekeluargaan, musyawarah mufakat dan religiusmagis dalam bentuk rasa malu pada leluhur jika apa yang diwariskan justru membuat damuh atau 
keturunannya terjadi disharmoni atau tidak jalannya nilai-nilai upeksa yaitu keseimbangan dalam hidup dan kehidupan.

Terkait dengan implementasi keputusan-keputusan adat, baik MUDP, MMDP, Majelis Alit dan tingkat kertha desa, prajuru desa adat adalah ujung tombak yang signifikan guna menentukan keberhasilannya. Mekanisme pengembilan kebijakan di desa adat, senantiasa mengutamakan uger-uger desa, baik dalam bentuk awig-awig, aturan tidak tertulis lain yang diyakini oleh masyarakat adat, juga yang sangat penting adalah perarem desa adat sebagai pemutus tertinggi kebijakan, terutama yang tidak diatur dalam uger-ugeran.

Pengambilan putusan dalam kaitan dengan perempuan berhak mewaris, desa adat sangat apresiatif terhadap kebijakan keluarga/krama desa adat dan masing-masing dadia, kecuali mereka minta bantuan desa adat untuk ikut menyelesaikan. Tentu dalam menentukan warisan sangat diperhatikan posisi warisan, apakah warisan harta pusaka, guna karya, paweweh atau tatadan, masing-masing punya proses pewarisan yang berbeda.

Sosialisasi pewarisan dari prajuru desa adat, sampai saat ini masih berpegang pada awig-awig desa pakraman dan dresta yang masih diakui oleh krama desa adat. Pernah ada kasus mengenai perempuan mewaris, tampaknya ada kesalahpahaman mengenai harta warisan, mereka menganggap tanah pekarangan desa diakui dan ingin dipindahtangankan ke anak perempuan. Kasus ini ditangani oleh prajuru desa adat Buleleng.
Bentuk pengambilan keputusan di wilayah adat sudah menyesuaikan dengan uger-uger adat yang berlaku di masing-masing daerah di Kabupaten Buleleng tempat penelitian dilaksanakan. Sistem pewarisan yang ada dalam masyarakat yaitu sistem purusa dengan adanya keputusan MUDP Bali No.01/Kep/PsM-3/Bali/2010 telah mampu diterima oleh sebagian besar oleh masyarakat Buleleng secara arif bijaksana. Secara realitas tim peneliti dapat menilai bahwa telah terjadi tanggapan positif dari masyarakat dengan isi keputusan tersebut. Hal ini sekaligus sebagai sebuah pembuktian kedudukan kaum perempuan Bali sudah memperoleh tempat tersendiri di dalam keluarga terutama dalam kaitannya di bidang pewarisan. Hasil penelitian ini menunjukkan adanya konstruksi kesetaraan gender oleh pihak laki-laki terhadap perempuan di Bali, sekaligus menghapuskan stigma bahwa perempuan Bali dalam kedudukan termarjinalkan. Pengaruhnya pada tatanan kehidupan sosial dan ekonomi perempuan Bali khususnya di kabupaten Buleleng tempat penelitian dilakukan, bahwa baik laki-laki dan perempuan dapat menjalankan profesi yang setara dan dalam kedudukan di dalam keluarga dikembangkan sikap saling menghargai sehingga dapat diamati tatanan khidupan harmonis sudah mampu dikembangkan.

Realisasi Isi Keputusan MUDP Bali No.01/Kep/PsM-3/MDP BALI/X/2010 tentang Perempuan Bali yang Menerima 1/2 Harta Warisan Purusa Setelah Dipotong 30\% untuk Harta Pusaka dan Kepentingan Pelestarian 
Pada umumnya sistem pewarisan pada masyarakat masih berpegang pada dresta, hukum adat dan juga awigawig, namun di desa-desa yang sudah agak modern seperti masyarakat Buleleng, ada yang memberikan waris pada anak perempuannya melalui nproses hibah, hal ini terjadi ketika runtuhnya kerajaan Buleleng. Sejak tahun 1935 Buleleng sudah tidak punya raja, raja Buleleng beralih ke agama Kristen.

Sampai saat ini Keputusan Pesamuan Agung III MUDP Bali tentang Hak Waris Anak Perempuan belum tersosialisasikan dengan baik, sehingga belum semua krama desa memahaminya, hal itu disebabkan MUDP, MMDP terkendala dana dan kegiatan mendesak lainnya seperti membahas posisi Lembaga Keuangan Desa, menyusun struktur Pecalang di tingkat Propinsi dan Kabupaten, Pemilihan Gubernur dan yang terakhir disibukkan dengan pembahasan Draft Undang-Undang desa sebelum lahir menjadi undang-undang desa No.6 tahun 2014.

Pandangan krama desa terhadap isi Putusan Pesamuan Agung III MUDP Bali banyak respon positif, hal ini terungkap lewat wawancara dengan Bapak Made Rimbawa mantan Ketua MMDP Kabupaten Buleleng. Sebenarnya isi Putusan Pesamuan Agung III tentang Anak Perempuan Berhak sudah ada terlaksana walaupun tidak sama persis dengan isi putusan, tetapi memberikan warisan kepada anak perempuan melalui proses hibah dengan kebijakan ndan kesepakatan anak laki-laki dalam keluarga, jadi musyawarah keluarga dan sikap legawa (mau menerima) pihak laki-laki sangat menentukan.

Krama desa adat pada umumnya merespon positif isi Putusan Pesamuan Agung III MUDP Bali, dengan alasan pemerintah sangat memperhatikan kesetaraan gender. Putusan Pesamuan Agung III MUDP Bali menurut Bapak Made Rimbawa adalah sesuatu yang patut sehingga perlu dilaksanakan dan selama masih relevan dengan tingkat kebutuhan hukum masyarakat tidak perlu dilakukan revisi lagi. Bapak Made Rimbawa selaku tokoh yang banyak bergelut dan menyelesaikan kasuskasus adat di tingkat Kabupaten dan Desa Adat memandang Isi Pesamuan Agung III Bali adalah sebuah pembaharuan yang sangat memberikan rasa keadilan, terutama kepada anakanak perempuan.

Krama desa adat sangat memerlukan adanya sosialisasi isi Putusan Pesamuan Agung III MUDP Bali, dan mereka pada umumnya berkeyakinan jika masyarakat adat Bali diberikan pemahaman terkait kesetaraan gender, maka isi putusan itu akan dapat terlaksana, walaupun mungkin akan ada kendala terutama dari anak laki-laki. Untuk dapat dilaksanakan isi Pesamuan Agung III itu, dirasakan sangat perlu adanya peraremperarem di masing-masing desa adat guna adanya pengenjuh awig yaitu penambahan atau perubahan awig-awig yang telah dimiliki dan berlaku.

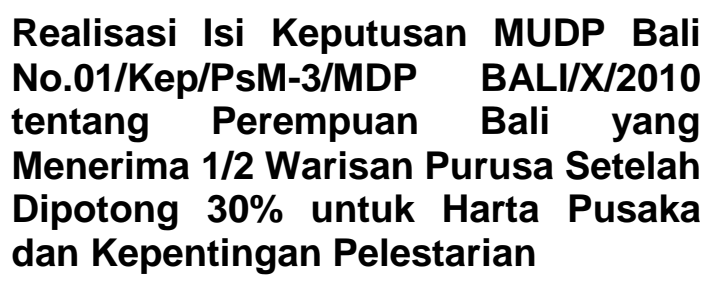


Perempuan menyambut baik Putusan Pesamuan Agung III MUDP Bali, mereka merasa pantas menerima waris dari orang tuanya, alasan samasama sebagai anak yang patut diberikan kasih sayang dan keadilan dalam segala hal, termasuk warisan, jika ada penerimaan warisan yang beda dengan anak laki-laki, itu tidak masalah mengingat ada perbedaan tanggung jawab.

Ada orang tua yang mengisahkan pemberian warisan kepada semua anak-anaknya, walaupun anak perempuannya warisan diberikan dalam bentuk paweweh perkawinan yaitu pemberian orang tua kepada anak perempuannya yang menikah sebagai modal hidup bersama dengan suaminya, memang paweweh itu tidak sama dengan yang diterima anak lakilakinya. Kebijakan orang tua seperti itu ternyata dapat diterima oleh anak lakilakinya. Hal itu menunjukkan semangat kekeluargaan dan sifat luwes dari hukum adat memberikan kontribusi yang besar dalam proses dinamika pewarisan adat di kabupaten Buleleng.

Di atas sudah disinggung, bahwa perempuan Bali sangat setuju jika diberikan hak mewaris, sekalipun jumlahnya tidak sama dengan laki-laki. Mengenai besaran jumlah warisan sesuai dengan Putusan Samuan Agung III menurut prmpuan adalah sangat ideal. Pemotongan 1/3 untuk harta pusaka dipandang sebagai kebijakan yang layak mengingat pemanfaatannya untuk kepentingan Merajan seperti benda-benda sakral. Hal itu, menunjukkan sifat regiusmagis tetap menjadi landasan filosofi perempuan Buleleng dalam menunjukkan sikapnya mengenai pewarisan.
Putusan Pesamuan Agung III MUDP Bali memberikan hak mewaris bagi perempuan, dalam perspektif perempuan dipandang sebagai cahaya terang yang apresiatif terhadap kesederajatan kaum laki-laki dan perempuan, meskipun asas Batan Lempeng ke Purusa tetap dihargai. Hal itu ditunjukkan dengan adanya prbdaan penerimaan waris dengan ketentuan "Ategen-Asuhun". Atau 2 banding 1 (laki-laki 2 perempuan 1).

Prajuru adat banyak berpendapat agar Putusan Pesamuan Agung III MUDP Bali segera direkomendasikan oleh MUDP kepada prajuru adat. Apabila adanya rekomendasi untuk melaksanakan, maka prajuru adat sebagai Hakim Mediasi dan perdamaian mempunyai landasan yuridis untuk berpijak ketika ada kasus-kasus pewarisan yang terkait dengan hak wanita mewaris.

Dalam aplikasi putusan Pesamuan Agung III MUDP Bali, mendapat respon negarif dari anak laki-laki yang kurang memahami asas komunalitas di antara anak laki-laki maupun perempuan, tetapi jika dilihat pemberi waris dalam bentuk paweweh tampaknya anak laki-laki pun tidak keberatan. Sesuai dengan perkemabangan zaman, pengaruh globalisasi dalam era kekinian, peran perempuan Bali akan meningkat dan pada akhirnya timbul perasaan menuntut hak yang sama (swadikara).

\section{Pengaruh dari Penetapan Isi SK MUDP Bali No.01/Kep/PsM-3/MDP BALI/X/2010 dan Daya Ikat Putusan MUDP terhadap Masyarakat Adat di Kabupaten Buleleng}

Sampai saat ini, karena Putusan MUDP blum disosialisasikan dengan 
baik, merata pada semua krama desa, kiranya sangat sulit mefrediksi atas dasar adanya sikap mental masyarakat dalam arti luas sudah banyak bergeser adanya degradasi moral, etik, mental spiritual. Ada kekhawatiran sikap mental masyarakat dalam arti luas itu dapat memberikan pengaruh juga kepada masyarakat krama adat, sehingga unsur-unsur perekat pelestarian nilai adat dan budaya Bali akan memudar, seperti nilai religiusmagis, komunalistik dan humanistik.

Memang aturan maupun materi Awig-Awig berdasarkan Bhisama, Dresta, maupun Perarem Paruman Desa, namun putusan Pesamuan Agung III MUDP Bali mempunyai kekuatan yang bersifat yuridis formal, dengan alasan bahwa MUDP Bali adalah lembaga adat yang sah keberadaannya, dan didukung oleh yurisprudensi Pengadilan Tinggi Bali, sehingga bagi krama adat mengenggap sah dan mengikat, namun hal dimaksud harus diakomodir terlebih dahulu pada AwigAwig Desa Pakraman sehingga mengikat masyarakat secara socio substansial.

Secara teori dan aturan yang berlaku SK MUDP Bali memiliki kekuatan mengikat, sebab:

1) Lahirnya MUDP Bali tanggal 24 Pebruari 2004 merupakan Lembaga Resmi berdasarkan Perda Propinsi Bali No.03 Tahun 2001 jo Perda Propinsi Bali No. 03 Tahun 2003.

2) Masyarakat Hindu Bali sebagai masyarakat mayoritas, belum memiliki hukum adat yang terkodifikasikan dengan baik, masih berpgang pada landasan ucapan "Mula Keto atau "Suba Dapet Keto".
3) Sudah adanya yurisprudensi dari Pengadilan Tinggi Bali yang intinya, hal-hal yang mengenai adat sepatutnya diselesaikan oleh lembaga adat seperti MUDP.

Berbicara mengenai masalah sanksi di desa adat, desa adat dengan prajuru desa adatnya berkapasitas sebagai lembaga adat yang sifatnya memediasi jika ada kasus-kasus adat sampai ke desa adat. Jadi, prajuru desa adat memposisikan diri sebagai hakim perdamaian yang berupaya meningkatkan kesadaran hukum adat Bali dan kesungguhan dalam merealisasikan ajeg Bali (Nginggilang) adat dan budaya Bali.

Melalui isi keputusan MUDP Bali, kedudukan perempuan Bali sudah memperoleh perhatian, hal ini perlu juga dikembangkan di masing-masing daerah. Lembaga daerah sudah memfasilitasi kebijakan status hukum perempuan di dalam masyarakat, untuk penghormatan pihak lawan jenis terhadap perempuan Bali diperlukan penyebarluasan informasi kepada publik salah satunya hasil penelitian ini telah menunjukkan adanya respon positif masyarakat Buleleng menghormati hak perempuan Bali dalam bidang kehidupan sosial dan ekonomi dengan kebijaksanaan memberikan kesempatan sebagai pewaris di dalam keluarga.

\section{PENUTUP}

Pengembilan putusan dalam kaitan dengan perempuan berhak mewaris, desa adat sangat apresiatif terhadap kebijakan keluarga/krama desa adat dan masing-masing dadia, kecuali mereka minta bantuan desa adat untuk ikut menyelesaikan. Untuk dapat dilaksanakan isi Pesamuan Agung III itu,

Jurnal IImu Sosial dan Humaniora |780 
dirasakan sangat perlu adanya perarenperarem di masing-masing desa adat guna adanya pengenjuh awig yaitu penambahan atau perubahan awig-awig yang telah dimiliki dan berlaku. Prajuru adat sebagai Hakim Mediasi dan perdamaian mempunyai landasan yuridis untuk berpijak ketika ada kasuskasus pewarisan yang terkait dengan hak wanita mewaris. Aturan maupun materi Awig-Awig berdasarkan Bhisama, Dresta, maupun Perarem Paruman Desa, namun putusan Pesamuan Agung III MUDP Bali mempunyai kekuatan yang bersifat yuridis formal, dengan alasan bahwa MUDP Bali adalah lembaga adat yang sah keberadaannya, dan didukung oleh yurisprudensi Pengadilan Tinggi Bali, sehingga bagi krama adat mengenggap sah dan mengikat.

Implementasi keputusan-keputusan adat, baik MUDP, MMDP, Majelis Alit dan tingkat kertha desa, prajuru desa adat adalah ujung tombak yang signifikan guna menentukan keberhasilannya yang senantiasa mengutamakan uger-uger desa, termasuk perarem desa adat.

\section{DAFTAR PUSTAKA}

Anggreni, Luh Putu. 2011. Kesetaraan Dalam Hukum Adat Balihttp://www.balisruti.or.id/keset araan-dalam-hukum-adatbali.html. Diakses tanggal 28 Juni 2013.Pukul 14.00 Wita.

Aripta Wibawa, Made. 2006. Wanita Hindu Sebuah Emansipasi Kebablasan. Denpasar: PT Empat Warna Komunikasi.

Bali Post. 2013. Wanita Bali Multi Fungsi tetapi Dipinggirkan. http:// www.balipost.co.id/mediadetail.ph p? module $=$ detailberitaindex\&kid $=3$ 2\&id=62487. Diakses tanggal 28 Juni 2013. Pukul 14.05 Wita.

Bayu Krisna, I Gusti Ngurah. 2011. Cara Pembagian Menurut Adat Hindu Bali. http://www.balipost.co.id/ mediadetail.php?module=detailber itaindex\&kid=32\&id=62487. Diakse s tanggal 28 Juni 2013. Pukul 14.30 Wita.

Fahmi, I. 2014. Etika Bisnis; Teori, Kasus, dan Solusi. Bandung: Alfabeta.

Jurnal Balisruti.2011. Suara Millenium Development Goals.(MDGs), Edisi No. 1 Januari-Maret 2011.

IIman Hadikusuma. 1987. Hukum Kekerabatan Adat. Jakarta: Fajar Agung.

Maya Kania, 2000. Analisis Yuridis Terhadap Hak Waris Anak Perempuan Pada Masyarakat Batak Karo Menurut Hukum Adat (Studi Kasus putusan Mahkamah Agung Republik Indonesia Nomor 1542/K/Pdt/1999" tanggal 24 Mei 2000. Yogyakarta: Tesis, Fakultas Hukum Magister Kenotariatan Universitas Gadjah Mada.

Ridwan Halim. 1985. Hukum Adat dalam Tanya Jawab. Jakarta: Ghalia Indonesia.

Rimawati, Tody Sasmitha. 2012. Hak Waris Anak Perempuan Pada Masyarakat Bali Berdasarkan Keputusan Majelis Utama Desa Pakraman Bali Nomor 01/KEP/PSM-3/MDP BALI/X/2010 Tentang Hasil Pasamuhan Agung III MUDP Bali. Yogyakarta: Laporan akhir penelitian, Sekolah Vokasi Universitas Gadjah Mada Subekti. 1991. Hukum Adat Indonesia dalam Yurisprudensi 
Mahkamah Agung cetakan ke 4. Bandung: Alumni.

Sulistyowati Irianto. 2005. Perempuan di Antara Berbagai Pilihan Hukum. Jakarta: Yayasan Obor Indonesia.

Wolk, H. I., Tearney, M. G., Dodd, J. L. 2001. Accounting Theory. A Conceptual and Institutional Approach. South-Western College Publishing, 5th Edition.

Windia., Wayan P. http://hukum online.com. 2014. Hak Waris Perempuan Menurut Hukum Adat Bali. Denpasar: Artikel IImiah FH UNUD.

Anggreni, Luh Putu. 2011. Kesetaraan Dalam Hukum
Balihttp://www.balisruti.or.id/keset araan-dalam-hukum-adat-

bali.html. Diakses tanggal 28 Juni 2013.Pukul 14.00 Wita.

Aripta Wibawa, Made. 2006. Wanita Hindu Sebuah Emansipasi Kebablasan. Denpasar: PT Empat Warna Komunikasi.

Bali Post. 2013. Wanita Bali Multi Fungsi tetapi Dipinggirkan. http:// www.balipost.co.id/mediadetail.ph p? module $=$ detailberitaindex $\&$ kid $=3$ 2\&id=62487. Diakses tanggal 28 Juni 2013. Pukul 14.05 Wita. Krisnawa. 